Historic, archived document

Do not assume content reflects current scientific knowledge, policies, or practices. 
$a S D \|$

.45936

Savannah River

Forest Station
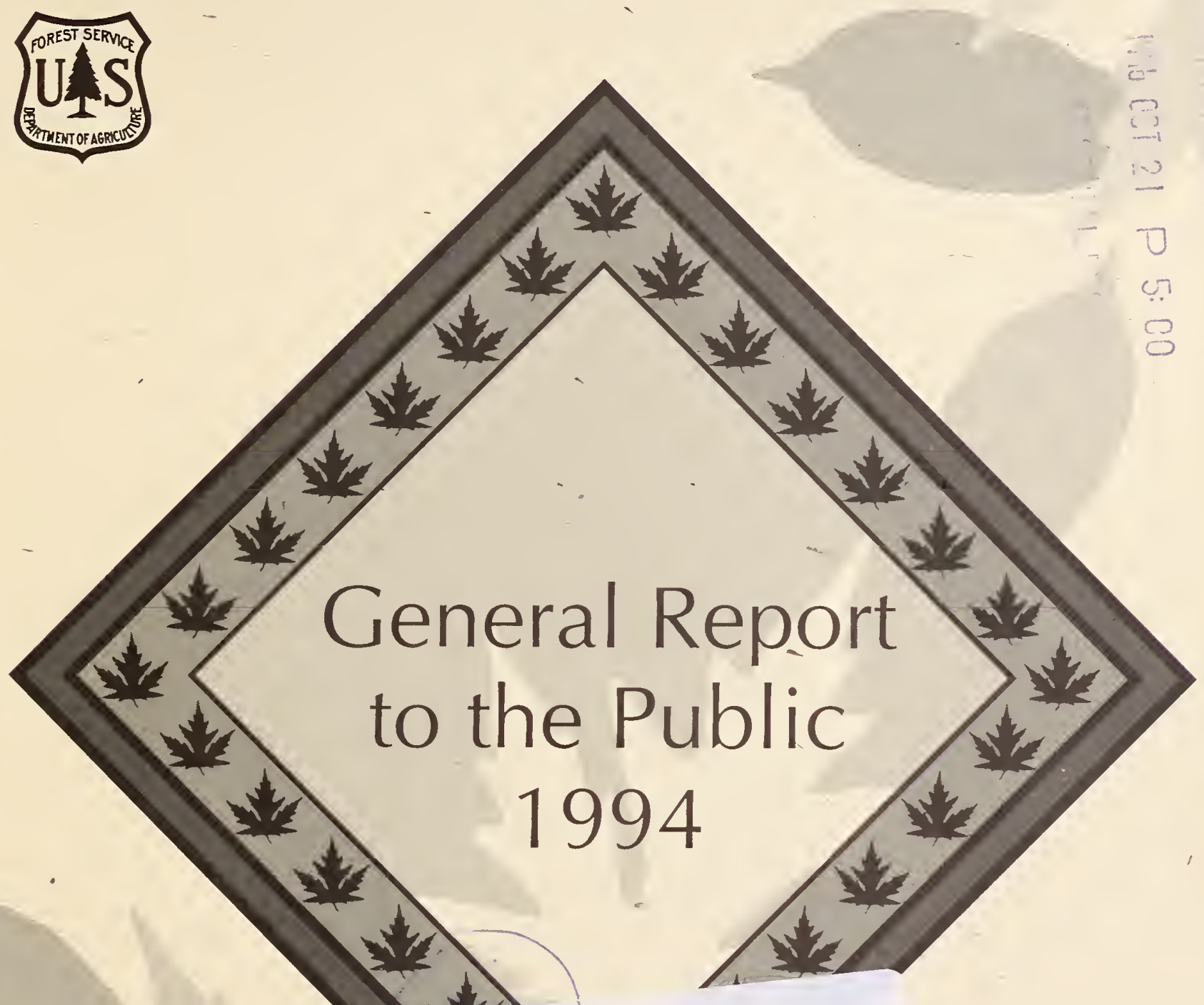

Savannah River Site New Ellenton, South Carolina 



\section{Table of Contents}

\section{Subject}

Letter from our Forest Manager

About Savannah River Forest Station

1994 Accomplishments

Wildlife, Fisheries and Botany

Research Support

Soil, Water and Air

Engineering

Safety and Environment

Timber Management

Fire Management

Public Affairs

Administration

Education

An Invitation to Comment

\section{Abbreviations}

The following abbreviations are spelled out when first mentioned on the following pages. However, by the time you reach page 9, you may not remember where they first appeared. The following list serves as a quick reference.

AEC - Atomic Energy Commission

CSRA - Central Savannah River Area

DOE - Department of Energy

GIS - Geographic Information System

RCW - red-cockaded woodpecker

SEFES - Southeastern Forest Experiment Station

SREL - Savannah River Ecology Laboratory

SRFS - Savannah River Forest Station

SRTC - Savannah River Technology Center USDA - U.S. Department of Agriculture WSRC - Westinghouse Savannah River Company 
Dear Friends:

As the Savannah River Forest Station (SRFS) concludes its fourth year in an expanded role of managing natural resources and coordinating research on the Savannah River Site (SRS), it has achieved many milestónes and exceeded planning objectives in numerous activities.

Following are some of our most notable accomplishments in fiscal year 1994 supported and funded by the U.S. Department of Energy (DOE).

We began the Natural Resources Mathematics, Science, and Engineering Program. The goal of this educational program is to enhance the math, science, and engineering skills of elementary schoolchildren in the Central Savannah River Area (CSRA). During its first year, the program included 17 schools and served more than 2,000 students. The program has been very well received and in the coming year will expand to include more than 40 schools reaching approximately 6,000 students.

We provided administrative support, site selection, and maintenance for 80 forest management and bioSiversity projects conducted by the Southeastern Forest Experiment Station, often in cooperation with numerous SRS organizations, universities, and research laboratories in the Southeast.

SRFS employees completed the first inventory of SRS secondary roads and exterior boundaries. In addition to other activities, the Engineering program expanded to plan and contract a number of construction and soil restoration projects for the site's primary contractor, Westinghouse Savannah River Company (WSRC).

Approximately 3,800 acres of soil stabilization and vegetative maintenance activities were completed by the SRFS Soil, Water, and Air management unit. Also, several watershed plans were prepared and designed to direct soil, water, and wetland protection site-wide.

The Wildlife, Fisheries, and Botany program continued to improve red-cockaded woodpecker (RCW) habitat by means of midstory removal. In only 9 years, the SRS RCW population has grown from 4 to 77 birds. Other notable accomplishments include a variety of ecosystem reclamation projects such as restoration of previously drained Carolina bays and the establishment of longleaf wiregrass communities.

In an effort to help DOE apply ecosystem management at its facilities, SRFS has organized a team to develop objectives and strategies for a site-wide ecosystem management program that will involve a number of organizations from both on and off site.

We had a timber sale program valued at more than $\$ 3.8$ million and reforested 2,059 acres to longleaf and loblolly pine and bottomland hardwoods.

We completed prescribed burning of 15,805 acres. This was done principally for RCW and other wildlife habitat improvement, and site preparation for tree planting. The SRFS fire organization controlled 15 wildland fires on SRS, allowing only 15 acres to be burned. The year, however, was marred by the death of SRFS firefighter Robert E. Browning Jr., in the Storm King Mountain incident in Colorado.

We contacted 30,431 people through a variety of public affairs activities, including a Smokey Bear 50th anniversary event targeted at elementary school children. As all DOE sites move toward more openness and public involvement, SRFS is increasing its activities to meet our communities' needs.

The Geographic Information System (GIS) team produced 25 layers of resource management and ecological resource data for SRFS use and to share with many other SRS organizations. In addition, they wrote programs to allow users to access GIS and produce maps without having formal training.

SRFS staff officers earlier completed and submitted to DOE 10 functional operations plans, a second level of planning mandated by our Natural Resource Management Plan, which provides objectives and strategies for forest management and research at SRS.

Our multi-cultural workforce has been expanded to 96 employees. We anticipate that administering a blend of ecosystem management and research projects will enhance forest productivity and critical threatened and endangered wildlife habitat as well as protect unique vegetative communities on SRS.

The SRFS procurement program exceeded \$1.6 million in fiscal year 1994. More than \$1.5 million of this involved procurements from small businesses in the CSRA.

Please visit us. We would like to show you what we are doing and hear your ideas about our present and future programs which are committed to meet Natural Resource Management objectives and to support DOE's mission for SRS.

Sincerely,

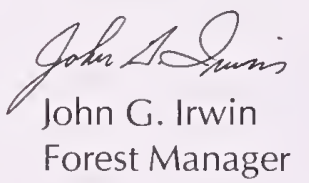




\section{Savannah River Forest Station}

The Savannah River Forest Station (SRFS) is a unique unit of the Forest Service, the largest agency in the U.S. Department of Agriculture (USDA). The mission of the Forest Service is to manage and protect the resources of our nation's forests and grasslands.

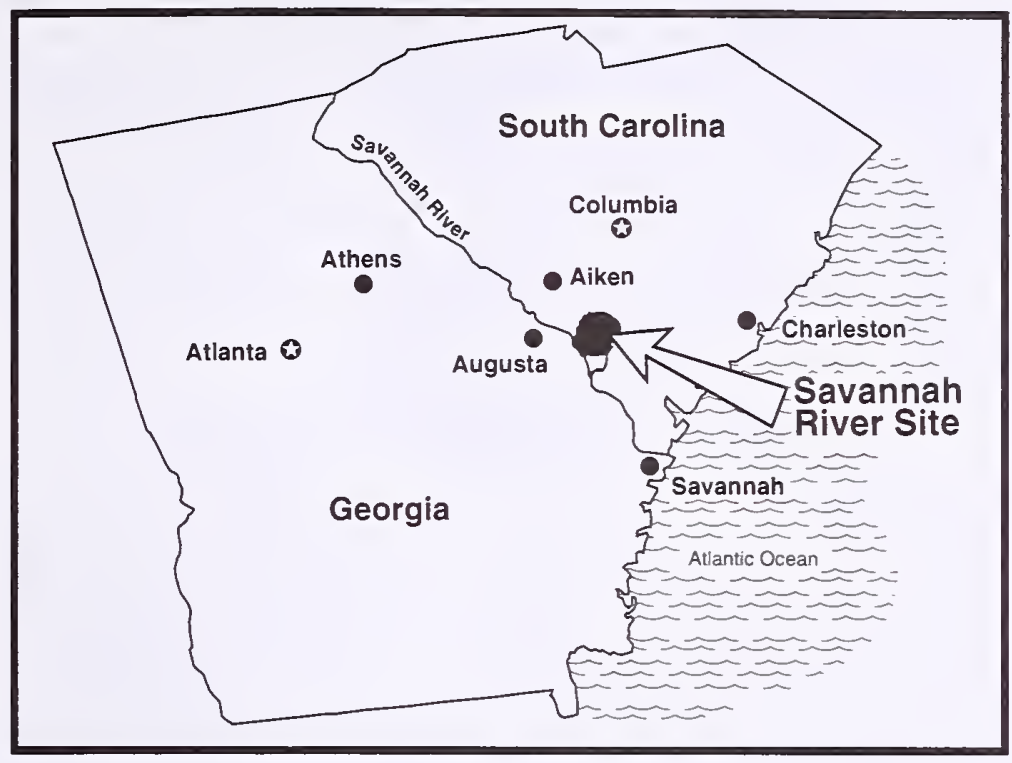

- The Savannah River Site, home of the Savannah River

Forest Station, is

located in South

Carolina along the

banks of the

Savannah River.
SRFS is different from other Forest Service units because it is not located on a national forest - it is located in South Carolina on the Savannah River Site, a nuclear materials facility owned by the U.S. Department of Energy (DOE) and operated by its primary contractor, Westinghouse Savannah River Company.

In 1952, DOE's predecessor, the Atomic Energy Commission (AEC), and the USDA Forest Service formed an interagency agreement to create an onsite forest management organization. Because the site was farmland before it was purchased by the Federal government, Forest Service employees' first task was planting trees by the thousands.

The 310-square-mile site is located in the western part of South Carolina, along the Savannah River on the Georgia-South Carolina border and located south of Aiken, SC, and southeast of Augusta, GA. The public has limited access to this Federal facility. All site workers, including those with the Forest Service, must obtain security badges to pass through guarded gates.

Although the site's mission is changing, its primary activities include recy- cling tritium (a radioactive gas) from the nation's weapons stockpile, mant aging radioactive waste, and performing environmental restoration activities. Approximately 21,000 people are employed at the site.

Only about 10 percent of the site is used for industrial purposes. Another 12 percent of the land is set aside for environmental research or otherwise excluded from management. SRFS is responsible for managing the natural resources on most of the remaining land - about 156,000 acres.

This limited-access area of land has become a unique wildlife refuge for a variety of plants and animals, including 50 threatened, endangered, or sensitive species, such as the red-cockaded woodpecker, the bald eagle, the smooth coneflower, Bachman's sparrow, and bog spice bush. Alligators, white-tailed deer, wild turkey, and many other species are also common on the site.

Because of this unique setting, in 1972 SRS became the nation's first National Environmental Research Park, a type of outdoor environmental laboratory, designated by the AEC. SRFS works with researchers to develop significant information relating to natural resource management, particularly endangered species management.

The work of the SRFS involves not only forest management, but also the recovery or maintenance of viable populations of native species. Additionally, Forest Service employees work with other on-and off-site groups to reclaim eroding land on site, maintain the site's secondary road system, prevent wildfires, support forestry research, and provide public awareness regarding wildlife, fire prevention, conservation issues, and career opportunities within the Forest Service. 
The SRS provides habitat that supports about 44 species of amphibians, 58 species of reptiles, 177 species of birds, 58 species of mammals, 79 species of fish, and more than 1,400 species of vascular plants.

The overall objective of the Station's Wildlife, Fisheries, and Botany (WFB) program is to provide the amount and mix of different habitats that will support viable populations of native plants and animals on the site. Management emphasizes recovery or maintenance of the 50 plant and animal species listed as threatened, endangered, or sensitive. Examples of these species include bog spice bush, Bachman's sparrow, smooth coneflower and red-cockcaded woodpecker (RCW).

The program accomplishes its objectives through direct habitat improvements, coordination with the timber program, and the manipulation of wildlife populations. Under the Natural Resources Management Plan, SRFS is responsible for a number of management and research related programs on site, including the fish and wildlife management program.

Accomplishments for fiscal year 1994 include: 1) Clearing 191 acres of undergrowth within RCW nesting habitat; 2) Placing 50 artificial cavity inserts for RCWs; 3) Mowing 255 acres of grassy openings; 4) Managing the quail habitat improvement cooperative project; 5) Monitoring and survey activities for wildlife and plant populations on about 18,600 acres; 6) Harvesting 1,641 deer, 783 hogs, and 174 beaver, and; 7) Increasing the site's RCW population from four in 1985 to 77 .

The Botany program manages several aspects of rare plant conservation as well as the restoration of native plant communities and habitats. The restoration of Carolina bay wetlands, a cooperative effort of several Forest Service units and the University of Georgia's Savannah River Ecology Laboratory (SREL), continues. These restoration

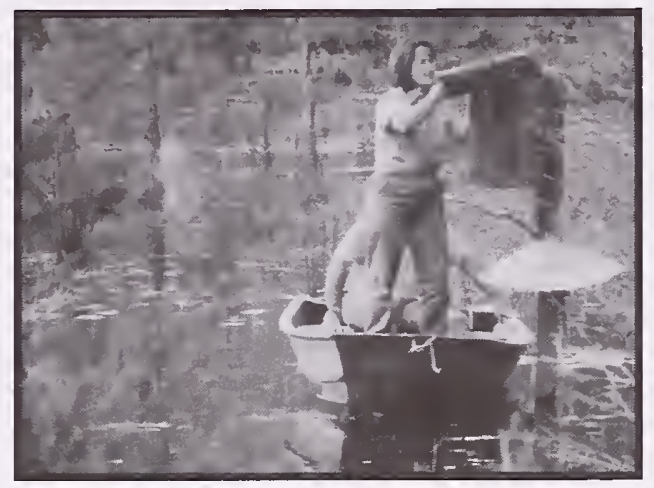

projects include selecting drained bays for timber removal and prescribed fire, plugging drainage ditches, coordinating these activities with researchers, and monitoring previously completed projects to ensure their success. Wiregrass reintroductions into the longleaf pine ecosystem continue. Plant surveys yielded about 30 new rare plant sites, including the discovery of a new colony of several hundred plants of the endangered smooth coneflower.

Working with SREL, SRFS provides recommendations to the site's managers regarding the size and harvest strategies for the white-tailed deer population. Using this information, a WSRC unit administers the hunts following Forest Service guidelines.

Ecosystem management is not an end in itself, but a means to achieve sustainable conditions and provide wildlife and fish habitat, outdoor recreation, wilderness, water, wood, mineral resources, and forage for society while retaining the aesthetic, historic, and spiritual qualities of the land. (A National Framework: Ecosystem Management; USDA Forest Service, 1994.)

Because the success of WFB programs is often dependent upon partnerships, cooperation continues with other site operators, including SREL and WSRC, the South Carolina Department of Natural Resources, and the Forest Service's Southeastern Forest Experiment Station (SEFES). Other partnerships continue to be developed with private organizations, such as Quail Unlimited, the National Wild Turkey Federation, and The Nature Conservancy. biologists check artificial duck nests for activity. SRFS helps provide a mix of habitats that support viable populations of native plants and animals on SRS. 


\section{Research Support}

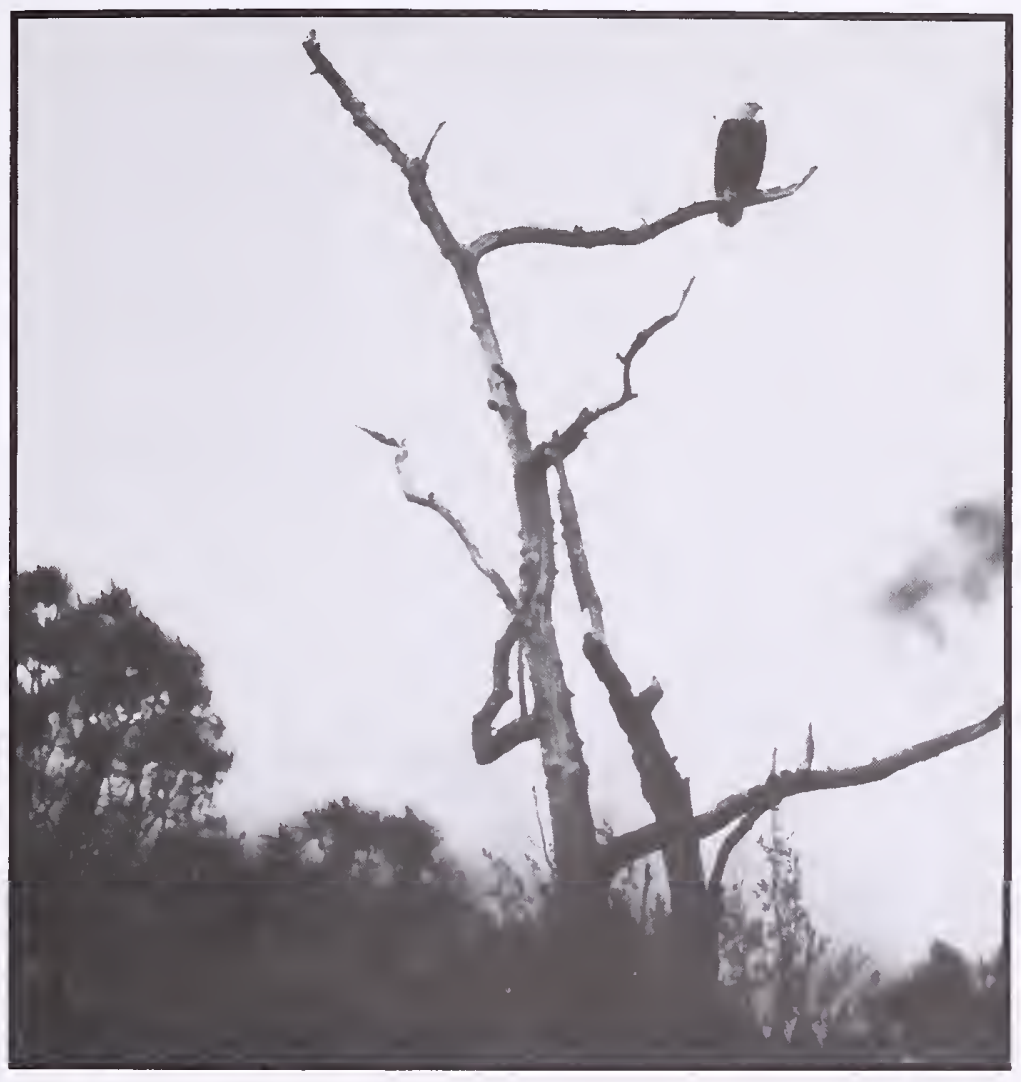

$\Delta$ A bald eagle surveys his domain. Several threatened and endangered species have made a comeback on SRS in the past several years.

SRFS provided extensive research support for various projects at SRS during fiscal year 1994. Support activities ranged from harvesting, silvicultural treatments, burning, and measuring research plots, to administrative support in developing programs, safety and security orientations, and preparing site-use permits. Station personnel maintained and protected more than 80 active research projects at the site.

An assistant manager for the research support program was hired in fiscal year 1991 to help coordinate support activities and to focus program objectives. This program has worked to archive documents published since 1953 about research programs supported by the Station, and to develop a listing of related

Ecology is the study of the structure and function of nature, it being understood that mankind is part of nature. (Eugene Odum, Quantitative Ecologist) publications. This list currently contains more than 300 scientific pubti cations.

\section{Biological Diversity Program}

The biological diversity program is a research program aimed at maintaining and restoring native species, while still meeting land management and facilities objectives. In 1989, SRFS initiated a program with the Savannah River Ecology Laboratory (SREL) and WSRC's Savannah River Technology Center (SRTC) to develop alternative strategies for biological diversity at the site while continuing to use resources and operate nuclear facilities. There are 41 active studies by the Southeastern Forest Experiment Station (SEFES) and various cooperators.

The biological diversity program will continue to emphasize conservation strategies for threatened, endangered, or sensitive species, restoration practices for hardwood and longleaf-savannah communities, landscape management principles and processes, and monitoring community attributes related to biological diversity. A major effort will be to link specific scientific questions to alternative land management strategies.

\section{Forest Operation Studies}

SEFES researchers and USDA Forest Service personnel from State and Private Forestry in Atlanta, GA, and Asheville, NC, have assisted SRFS in improving forest productivity and operational efficiency since 1952. Research personnel completed a herbicide dissipation study in 1994, which determined the fate of commonly available herbicides. Currently, the SRFS has 23 studies dealing with various aspects of seedling re- 
generation, litter raking, forest diseases, herbicide use, and smoke management. New equipment was developed in 1994 to improve control of Heterobasidion annosum root rot. The Station will assess this spray devise for treating stumps in 1995. Research personnel initiated root rot control to maintain the health of timber stands as habitat for the redcockaded woodpecker. They also remeasured and thinned a long-term litter raking study in 1994.

Pine straw is an important commodity for many landowners in the Southeast. About 1,500 acres of oldfield stands are annually harvested on the site. Researchers are assessing the potential impacts of these practices on long-term productivity. Dr. Paul Kormanik started a research project that deals with the importance of root quality in early development of hardwoods and pine and remeasured older research plots. These findings will help implement better nursery management strategies and improve survival and growth in field plantings. Researchers are also assessing a new smoke dispersion index for use in South Carolina.

Ecosystems are naturally occurring assemblages of species, living in and interacting with the same environment; these species are mutually sustaining and independent. (Eugene Odum, Quantitative Ecologist)

\section{Red-cockaded Woodpecker Research}

In 1985, the site was home to four red-cockaded woodpeckers, an endangered species. That included one breeding pair and two bachelor males. By 1994, there were 77 birds.

This recovery is a result of a close working relationship between SEFES and SRFS, and it is primarily attributable to the application of several techniques. These include translocation of birds from the Francis Marion and Sumter National Forests in South Carolina and the Apalachicola National Forest in Florida, and the development of an artificial cavity insert technique developed by SEFES personnel. SRFS personnel combine these techniques with habitat enhancement to control mid-story vegetation, using a combination of fire, mechanical and chemical treatments, and removing flying squirrels that compete for nest cavities. The research program currently focuses on direct competition effects from flying squirrels and snakes, and quantifying their effects on nesting success. Other research is aimed at determining the biological basis for foraging and food sources. Studies in the last year found that about 70 percent of the RCW diet in spring/summer consists of wood roaches. Researchers are also developing a mobile aviary to aid in the translocation of mature pairs.

\section{Wetland Restoration}

SRFS and SEFES are working with SRTC and other organizations to develop information on restoring and enhancing degraded wetlands on site. Dr. Bill McKee is overseeing vegetation and hydrology surveys at Pen Branch and Four Mile Creek.

Researchers began site preparation and planting of the Pen Branch corridor in 1993 and will complete this work in 1995-96. They will plant mixed bottomland hardwoods and cypress in this area. They are also continuing several wildlife baseline studies involving birds, reptiles, and amphibians. 


\section{Soil, Water, and Air}

A major mission of the Soil, Water,

We won't be a
society if we
destroy our
environment.
(Margaret Mead,
1901-1978,
American
Anthropologist)
and Air (SWA) unit is to provide technical support to other groups on site involved in engineering, and erosion and sediment-control projects. This is accomplished by providing workshops for site personnel, involving SWA staff in specific erosion control measures, continuing watershed stabilization and maintenance activities, and environmental restoration projects, and being a partner in the development of an onsite watershed/ ecosystems plan.

In fiscal year 1994, SWA personnel provided six workshops on the following topics: 1) Wildlife Management detailing how wildlife is managed (including deer hunts); 2) Best Management Practices Installation, demonstrating on-the-ground erosion control products by different companies; 3) Wetlands Mitigation, which explains what it costs and what practices are commonly used to meet regulatory mandates for compensation of wetlands damaged or destroyed during construction, and Constructed Wetlands, used for the treatment of effluents and stormwater retention; 4) Pesticide Use/SRS Policy, giving an overall view of how pesticides are used on site; 5) A field trip to Fort Jackson in Columbia, SC, to view the steps another government facility has taken to make watershed improvements, and; 6) A new products demonstration and display, where companies producing erosion control products could display and discuss their products with people from the site. Attendance was high for these workshops because of the increased demand for the type of knowledge being offered.

SWA personnel completed watershed stabilization on 211 acres at 16 different areas. Stabilization projects usually begin with bare areas. Techniques such as hand seeding, no- till drilling, liming, fertilization mulching, planting shrubs, drop strư tures, and other treatments are used tô establish vegetation for erosion control. The SWA group maintained a total of 3,528 acres. Maintenance projects include re-seeding, liming, fertilizing, mowing, aerating, controlling undesirable species, and ant abatement.

A detailed inventory identifying significant watershed improvement needs of the site was completed by SWA personnel. They chose 13 areas that need erosion control and completed an extensive evaluation program. They rated each area for its potential for surface water/wetland impact, erosion rate, erosion repair plan design, eroded area, and repair cost estimate. By the end of 1995, restoration of these areas should be complete, or in the final stages of repair. SWA also completed GIS hydrological mapping for use in site-wide watershed planning.

SWA personnel have planned a variety of projects for fiscal year 1995, and nine workshops are being discussed. One example is a cooperative class with Aiken Technical College to identify areas on campus with erosion control problems, and to use the class to set up a watershed plan and make necessary repairs. Other examples are a tour of Federal Paperboard Corp. to observe their water treatment processes and a tour of the site to visit inprogress restoration work. SWA personnel also started a comprehensive plan for the 4,194 acre CrouchMcQueen watershed in 1994; completion is planned for early 1995 . Future plans include the F-Area watershed and the Central Shops Area. 


\section{Engineering}

The original mission for Engineerfng personnel was to manage the site's secondary roads, boundary, 教n the Station's fleet and facilities. Although work continues in these areas, Engineering personnel have expanded into many new ones.

In fiscal year 1994, Engineering maintained 1,350 miles of sec-

t ondary roads and constructed 8.35 miles of new road. They completed Global Positioning System (GPS) mapping of the secondary road system, for a total of 873 miles. They are reducing this data for input to the Geographic Information System (GIS ), which will be available to all site users.

Boundary management generated more maintenance projects than expected, with 52 repair projects and replacement of 8.2 miles of fences. As required in the Boundary Management Operations Plan, Engineering personnel annually inspect the site boundary. This inspection data is used to develop maintenance plans for fence repair or replacement, fire break maintenance, sign replacement, and to inform site security of trespass evidence.

The cartography and photography program has continued to grow. Personnel completed seven projects, with over 56,216 acres photographed, and approximately 640 acres mapped.

The unit continues to provide civil engineering design and consultation support to the SRFS Soil, Water, and Air program, WSRC, SREL, DOE, and subcontractors on a wide variety of projects. Some of the projects include the Mixed Waste Management Facility Spoil Pile restoration, C-Area channel reconstruction, Carolina bay closures, road construction of monitoring wells, and Par 


\section{Safety and Environment}

SRFS strongly supports DOE's policies putting the safety and health of all SRS employees and sub-contractors first in all situations. To that end, the Station employs one environmental coordinator, one assistant environmental coordinator, and one safety and occupational health specialist.

SRFS is the Forest Service unit that enforces Occupational Safety and Health Act (OSHA) regulations with cooperator and sub-contractor activities and SRFS employee projects. In addition, the Station must comply with the USDA Forest Service Health and Safety Regulations and DOE safety orders.

Environmental Safety and Health (ESH) personnel verify program compliance for various safety laws and regulations by inspecting contractor and SRFS crews. When conducting these inspections, safety personnel must follow the guidelines set by the Forest Service, DOE, and OSHA. They spend considerable time researching OSHA regulations to facilitate more effective inspections. Also, the Station undergoes annual unannounced field assessments administered by DOE. Each requires from 3 to 9 days to complete.

The Station's environmental programs include waste management, waste minimization, pollution prevention, waste characterization, hazard communication, chemical coordination, and spill prevention/ countermeasure. DOE ensures that the Station complies with applicable DOE and Forest Service health, safety, and environmental regulations through comprehensive compliance assurance reviews of various programs. These include industrial hygiene, hazardous waste management and waste streams, non-radio- logical air pollution control, radiation safety, toxic and hazardous subs. stance control, and spill prevention, control and, countermeasure. In addition, ESH personnel annually conduct various other assessments.

A big task for environmental personnel is developing and updating plans and best management practices that provide guidance for the Station's various environmental programs. They continue to administer an in-depth self-assessment health program which they developed in fiscal year 1992.

ESH personnel attend training courses in industrial hygiene, industrial toxicology, hazardous waste operation, emergency response, and hazardous chemicals management. They also have attended extensive OSHA compliance training at the OSHA Training Academy near Chicago, $\mathrm{IL}$, as well as training provided by WSRC, such as environmental coordinator training.

Let us not go over old ground, let us rather prepare for what is to come. (Marcus Cicero, Roman Statesman, 106-43 B.C.) 
1 When first invited to the site in 952, the Station's primary responsibility was to plant trees on the acquired farmlands and other properties within the site boundary to promote soil stabilization. As these trees grew, the program expanded to include timber harvesting and reforestation. In 1993, SRFS expanded its Eenetics program to include hard1 woods. Both the longleaf pine and hardwoods genetics programs will include a seed orchard to provide genetically improved seed for longrange needs.

SRFS sold almost 25 million board feet of pine sawtimber and roundwood products in fiscal year 1994, returning approximately $\$ 4$ million to the U.S. Treasury, including one sale that brought a record $\$ 489.82$ per thousand board feet. SRFS also is continuing a program to sell pinestraw (freshly fallen longleaf pine needles) which netted $\$ 89,480$, or $\$ 200$ per acre, in fiscal year 1994.

Because forest scientists now have developed a system to grow highquality longleaf pine seedlings in the nursery, and a system to achieve high survival in forest plantations, SRFS is continuing a program of replacing non-native slash and loblolly pines on the dry sandhill areas with the more ecologically suited longleaf pine. These stands also will provide preferred future feeding and nesting habitat for the red-cockaded woodpecker. In 1994, SRFS planted 2,059 acres. This includes 1,672 acres of longleaf pine, 297 acres of loblolly pine, and 90 acres of mixed hardwoods on moister sites more suitable for their growth.
Two-person tree seedling planters were used by SRFS in the 1950's to reforest site farmlands. Today, SRFS's mission has expanded to total ecosystem management.

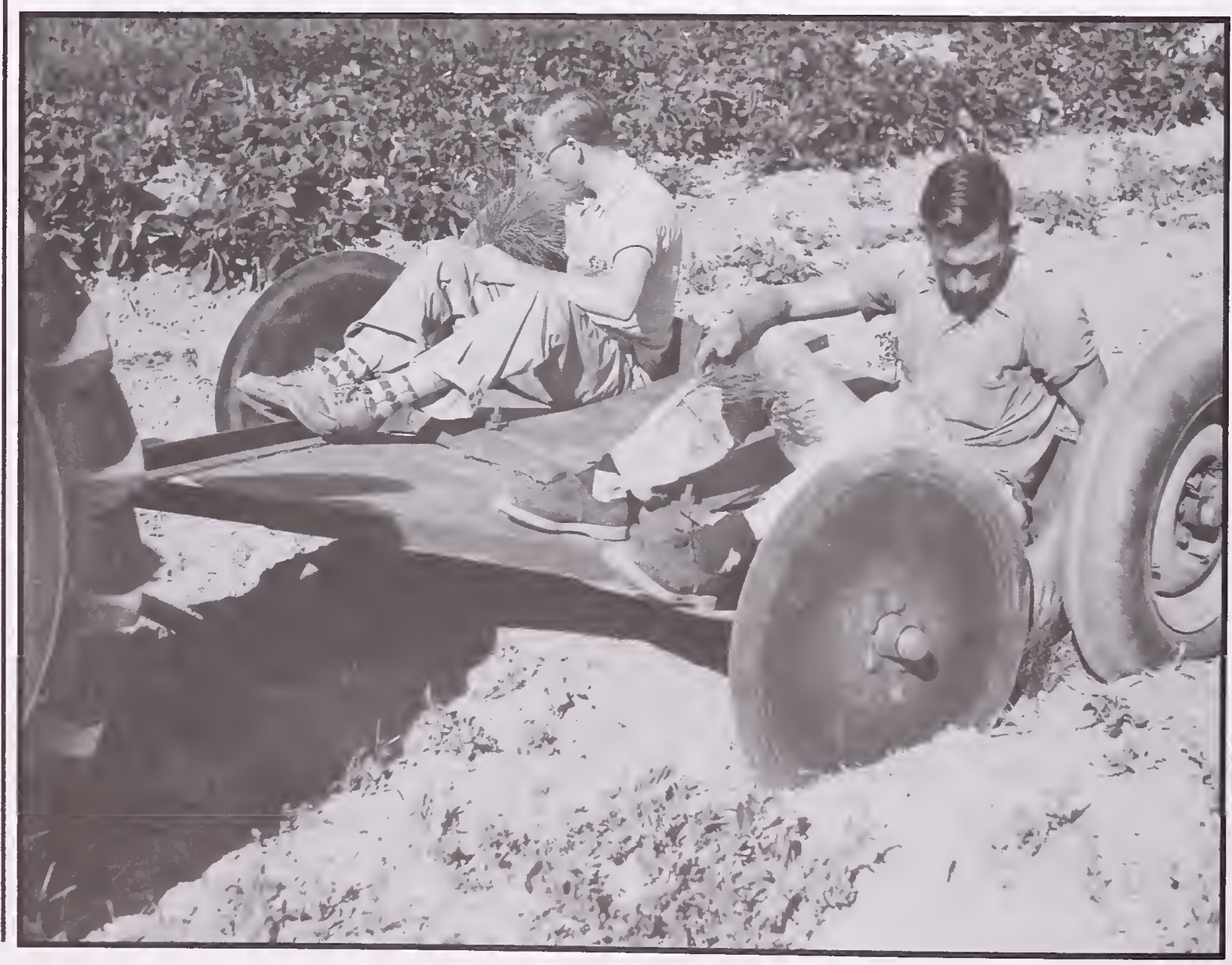




\section{Fire Management}

The Fire Management program's mission is to protect natural resources and SRS facilities from potential loss or damage by wildland fires, and to improve a variety of forest resources through the use of prescribed, controlled fires.

In fiscal year 1994, SRFS responded to 18 wildfires on and adjacent to the site. Three of these fires were in the mutual threat zone where the South Carolina Forestry Commission has primary protection responsibility. The remaining 15 fires burned 15 acres on the SRS.

In addition to suppression activities on site, SRFS supported national forests by sending equipment, support staff, and firefighters to assist

SRFS firefighters conduct a controlled burn to reduce wildfire

hazards and enhance wildlife habitat. SRFS is also responsible for controlling any wildfires on SRS.

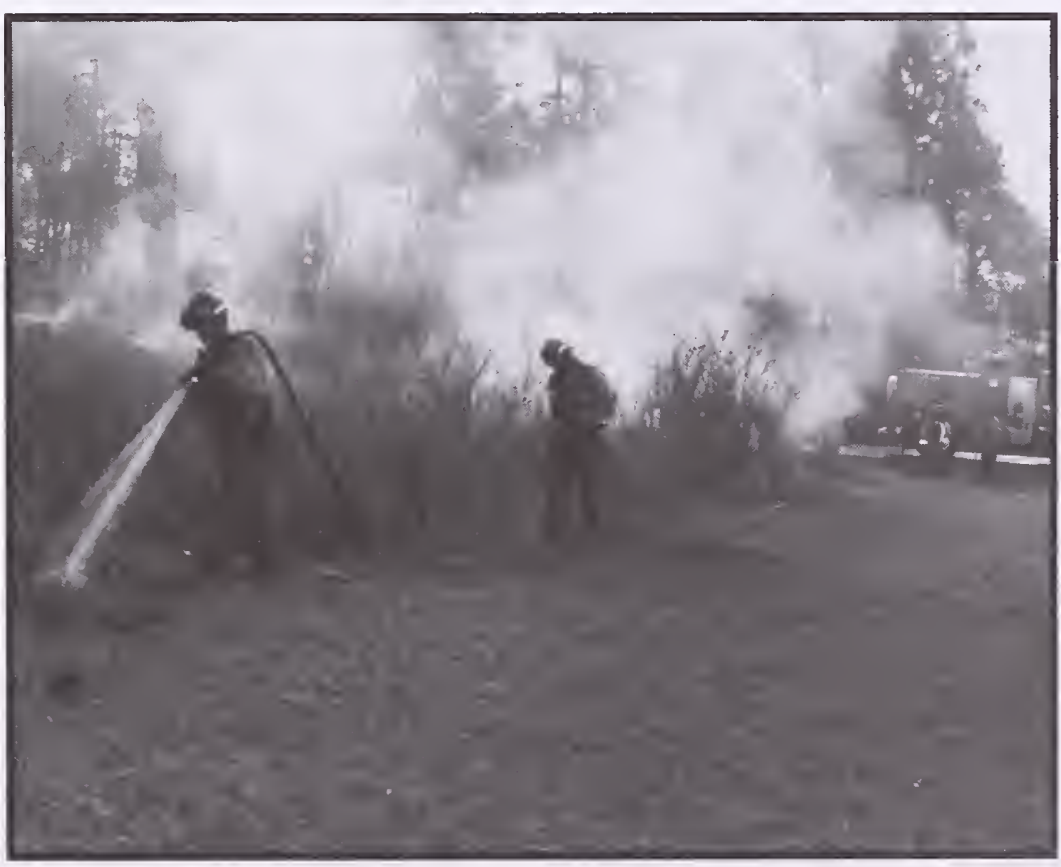

scribed burned in fiscal year 1994.

SRFS contracted its first fixed de tection program in 1994. The Station contracted the daily staffing of the Dunbarton and Cassels fire towers on a 3-year, annually renewable contract. The Station is evaluating its detection programs and will be determining what mix of detection is best to meet site needs.

The fiscal year 1994 fire prevention program was once again very active, especially in local elementary schools. Through the Smokey Bear School Program, approximately 3,800 schoolchildren in grades kindergarten through three were contacted in Aiken, Barnwell, and Allendale counties. Also, in partnership with the Georgia Forestry Commission, SRFS sponsored a Smokey Bear 50th Birthday Celebration. The event was held at Daniel Field Airport in Augusta, GA, and was attended by 8,500 people, mostly elementary school children. Smokey also appeared in several local events, including the Aiken County Emergency Responders Appreciation Day parade.

SRFS was profoundly affected by the July death of CO-worker Robert $E$. Browning Jr., one of 14 firefighters who died in the Storm King Mountain incident in Colorado. He was eulogized in a memorial service planned by SRFS employees. Many people at SRFS worked to assist the family, co-workers, and others during this difficult time. 
SRFS's Public Affairs Office (PAO) continued to increase its activities on and off site during fiscal year 1994. Earious groups, or "publics," are interested in SRFS activities, and this program works to provide information about those activities - thereby enhancing working relationships and increasing both the site's and SRFS's effectiveness.

The Public Affairs staff increased by one specialist during the fiscal year. That resulted in increased internal communications, special events, proactive media contacts, and submission of articles and news releases to a variety of specialty publication (both on- and off-site) and traditional media outlets.

Media relations activities involved promoting the accomplishments of various research and management programs and responding to media inquiries about SRFS employees who are dispatched to wildfires or other natural disasters. For example, PAO assisted a local television reporter follow a group of local firefighters onto the western fire lines. PAO also assisted the Fire Management program with improved public and site notification of controlled burns.

PAO personnel compile, edit, and distribute a monthly briefing page of noteworthy accomplishments to many of its publics. PAO distributes this simple Highlights publication to about 125 people throughout the country, and it has proven to be a successful communication vehicle for SRFS.

The Highlights also is distributed internally, and is part of a growing internal communication program. As the size of SRFS's workforce grew, so has the need for increased internal communication. Management meeting notes now are distributed to the unit. PAO coordinates quarterly fullstaff meetings to discuss issues and distribute awards. PAO also distributes flyers, messages, or articles throughout the unit.

Special-event planning in fiscal year 1994 focused on the 50th anniversary of the Smokey Bear Fire Prevention Program. Public Affairs, in conjunction with the Fire Management program, coordinated an April special event with the Georgia Forestry Commission (GFC) in Augusta, GA. At Augusta's Daniel Field Airport, about 8,500 school children and their escorts saw the Friends of Smokey Bear Hot Air Balloon, visited environmental displays, and saw a helicopter demonstration. The event, which was managed using the Incident Command System (the same system used in wildfire response), involved employees from every unit of the SRFS, along with volunteers and employees of GFC, the South Carolina Forestry Commission, DOE, WSRC, and the U.S. Fish and Wildlife Service. In addition, many of the requirements for the special event (such as the use of the airport, food, drinks, and even golf carts) were donated by local businesses. A short video of the event, produced by WSRC Video Services, is available from SRFS.

SRFS representatives made another 8,000 contacts during SRS Appreciation Days held at a local mall throughout a spring weekend. Smokey Bear talks or appearances accounted for another 7,000 contacts. The unit also has a traveling exhibit of native wildlife, a general exhibit, an exhibit about careers in the Forest Service, and a special children's display focusing on Smokey's birthday. Other contacts included tours for Clark Atlanta Uni- 


\section{Public Affairs (Continued)}

versity students, garden clubs, and professional groups, such as the Hitchcock Foundation Board; presentations to school groups, including handicapped children; and presentations at career fairs, parades, fishing rodeos, and other environ-

The nine-story tall Smokey Bear hot air ballon was the centerpiece of a 1994 birthday celebration co-sponsored by SRFS. After 50 years, Smokey's message is still relevant: Remember... Only You Can Prevent Forest Fires. activities, SRFS personnel made an estimated 30,431 personal contacts during fiscal year 1994, comparéd to 16,005 contacts made in fiscal. year 1993. Because two large events skewed the number of contacts reported, that number should decline in fiscal year 1995 .

Public Affairs Office personnel assisted with the memorial service for Robert E. Browning Jr. and handled media inquiries. They also worked to brief co-workers of any forthcoming news items. That work continued, as the casualty investigation reports required additional media and internal audience briefings.

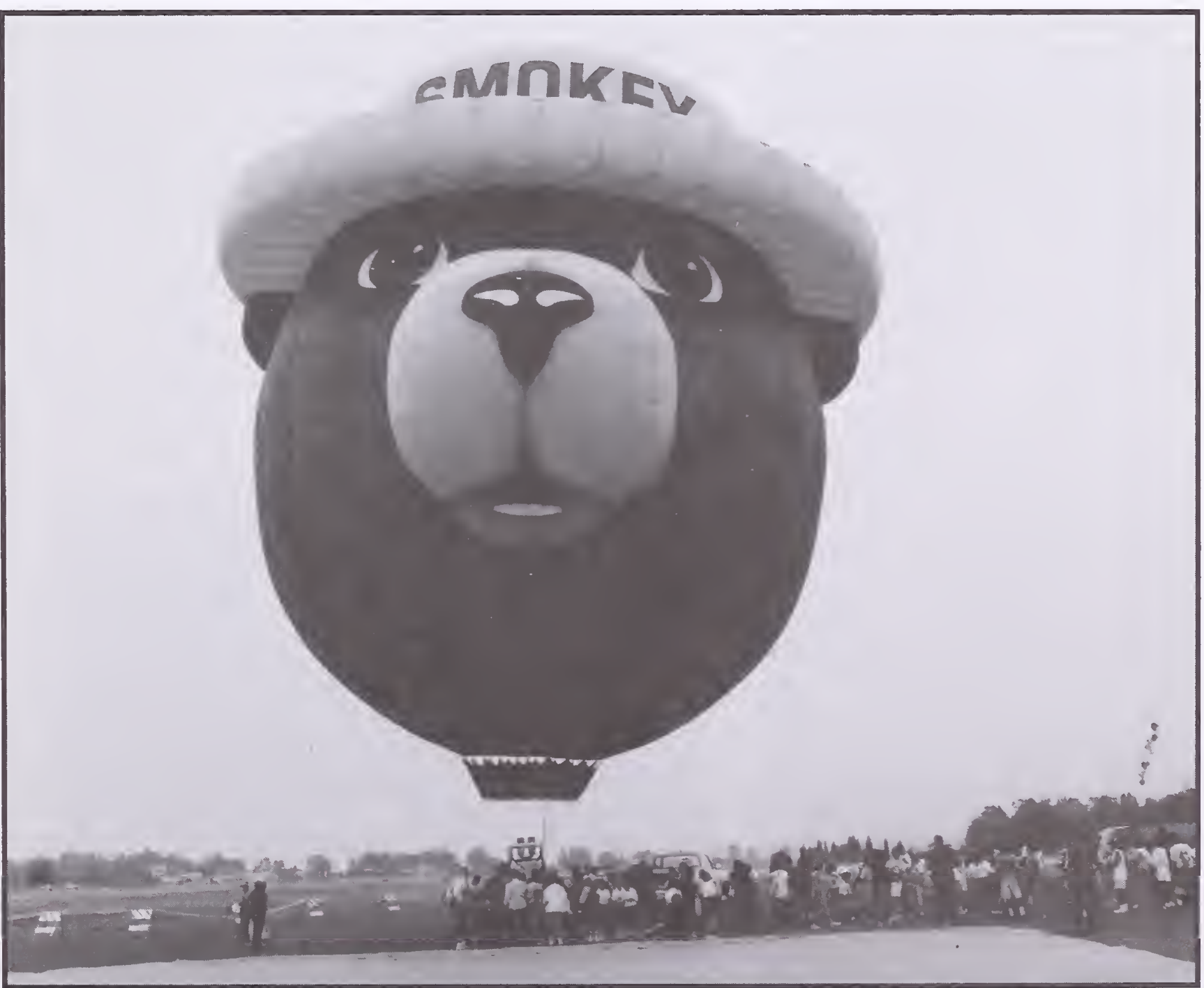


Administration

The SRFS workforce consists of 96 pormanent positions. The workforce has increased from 24 employees in is effectively implement the SRS Natcural Resources Management Plan. Currently, the Station management team is reviewing the organizational structure to determine additional personnel increases needed to assume a greater involvement with environmental cleanup projects at SRS and to respond more readily to environmental-related inquiries from DOE.

SRFS also supports the Senior Community Service Employment Program. The program provides employment for eight local, low-income senior citizens. Senior citizens participating in this program are not only provided with employment, but also are given a sense of enhanced self-esteem and a feeling of contributing to their local community. The Station also supports local historically black colleges and universities and 1890 Land Grant schools by offering annual summer employment.

\section{Procurement}

The SRFS fiscal year 1994 procurement program exceeded $\$ 1.6$ million. The work load included 17 contracts awarded for amounts exceeding $\$ 25,000$ and 1,200 small purchase transactions. Included in these actions were procurements from "8a" minority firms $(\$ 361,098)$, minority-owned businesses $(\$ 38,384)$ and womenowned businesses $(\$ 25,000)$. Total procurements from small business organizations totaled more than $\$ 1.5$ million.

\section{Budget and Finance}

The budget and finance group ac- counted for salaries and other expenditures totaling more than $\$ 9.5$ million during fiscal year 1994. The accounting personnel find their jobs a bit unique and more difficult than their counterparts at other Forest Service units because they convert DOE budget and reporting codes into Forest Service appropriations and management codes. Later, they must reverse the process when preparing billing statements for submission to DOE. With continuing program expansion, the budget for fiscal year 1995 is $\$ 15$ million.

\section{Management Systems}

The management systems group had a very productive fiscal year 1994. They continued to provide computer support to the unit through the Forest Service computer system and the site's computer system. Personal computers also are used by several staff areas to enhance the efficiency of those operations through the use of modern software programs. The Geographic Information System (GIS) established at SRFS in fiscal year 1991 continued to be upgraded with additional equipment, software, and digitized layers of data for use in deciding natural resource management decisions for the site. Programs were written to allow users to access GIS and produce maps without having formal GIS training.

GIS is a computer system that is capable of storing, analyzing, and presenting geographic information. The data in GIS is stored in thematic layers. Methods for creating data layers include digitizing, or electronically tracing, features from existing paper maps, scanning aerial photographs, and incorporating digital satellite images. Another method for creating data layers is by 


\section{Administration (Continued)}

using Global Positioning system (GPS) receivers which determine one's position on Earth by analyzing coded signals sent from a network of navigational satellites orbiting the planet. During fiscal year 1993, Management Systems installed a local area network and three X-terminals to provide all disciplines with

\section{Education}

School children

learn about

the ecological

dynamics of a

Carolina bay.

During its first

year, the education

program at SRFS

has enhanced the

math, science, and

engineering skills

of more than 2,000

students in the

CSRA.
The SRFS began the Natural Resources Math, Science, and Engineering Program (NRMSEP) in fiscal year 1994. The goal of this program is to enhance mathematics, science, and engineering interests and abilities of school children in the Central Savannah River Area of South Carolina and Georgia. The program conducts "hands-on" activities at the site in which students at various grade levels apply mathematics, science, and engineering principles to natural resource and environmental problems. The program is designed to increase the students' understanding of their natural resources and the environment, while increasing mathematics, science, and engineering skills. Students visit several times during the school year to conduct special class activities. Students in

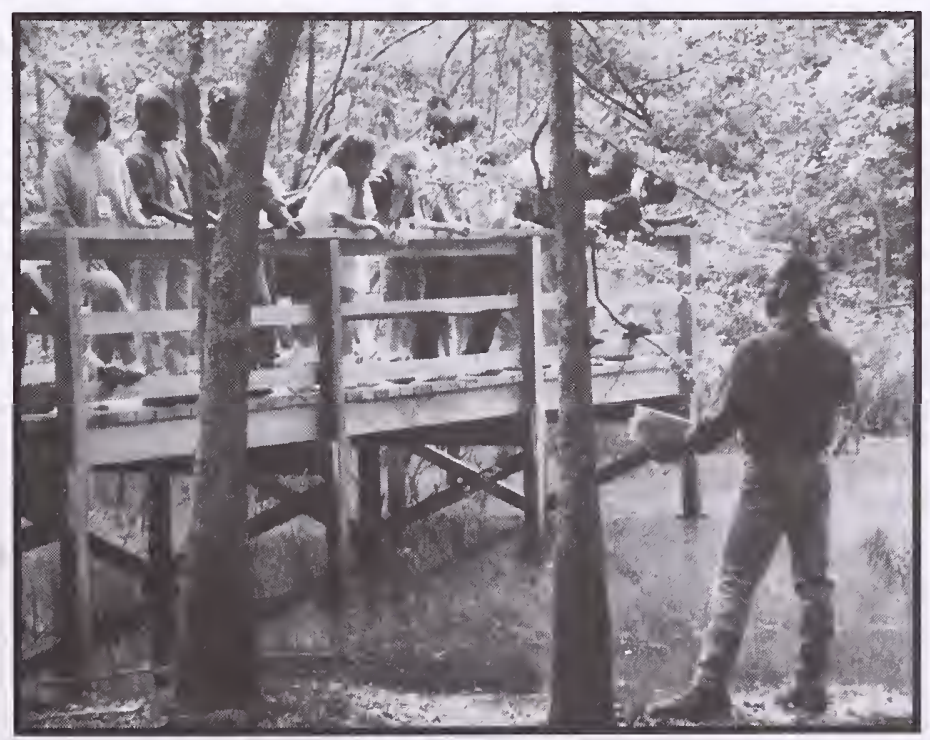

grades 3 to 12 are eligible to participate in the program.

DOE, the University of South Carolina-Aiken, and the Forest Service cooperatively developed and manage the program. Initial funding of $\$ 200,000$ was provided by the South Carolina Universities Research and Education Foundation. SRFS provides logistics and liaison support, as well as an educational specialist to develop the program. A team of master teachers from the Aiken County school system has been an active partner in developing the curriculum. WSRC and the University of Savannah, Carolina Institute of Archaeology and Anthropology provided support and assistance in implementing the program, and they will continue to participate.

During its first year, the program included 17 schools and served more than 2,000 students. Approximately 300 teachers were involved in workshops to develop their skills in teaching mathematics and science. The education program offered two summer camps for students. In addition, a number of teachers correlated NRMSEP activities with goals of the National Council of Teachers of Mathematics and Project 2061.

In the coming year, the program will expand to include more than 40 schools reaching about 6,000 students. 
An Invitation to Comment

This report will be published annually by the Savannah River Forest Station. You also may obtain additional information on any project by contacting the Forest Manager, Savannah River Forest Station, Savannah River Site Building 360-G, P.O. Box 710, New Ellenton, SC 29809-0710, or by calling (803) 725-

2441. We welcome your comments. For your convenience, we have prepared the following questionnaire. To send it to us, please use site mail, or enclose in an envelope and mail to the address above.

What topics are important to you? Here are some you might consider:
- Biological Diversity
- Roads
- Education/ Outreach
- Soil and Water
- Forest Planning
- Wildlife
- Timber
- Native Plants
- Endangered Species
- Fire Prevention

— Please keep or add my name to the Savannah River Forest Station mailing list.

- Please remove my name from your mailing list.

Comments:

Please print clearly 

The United States Department of Agriculture (USDA) prohibits discrimination in its programs on the basis of race, color, 'national origin, sex, religion, age, disability, political beliefs and marital or familial status. (Not all prohibited bases apply to all programs.) Persons with disabilities who require alternative means for communication of program information (braille, large print, audiotape, etc.) should contact the USDA Office of Communications at (202) 720-5881 (voice) or (202) 720-7808 (TDD).

To file a complaint, write the Secretary of Agriculture, U.S. Department of Agriculture, Washington, DC 20250, or call (202) 720-7327 (voice) or (202) 720-1127 (TDD). USDA is an equal employment opportunity employer.

\section{Forestry Report R8-FR51}

April 1995

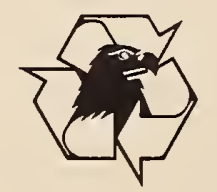

Printed on recycled paper 